\title{
RELATIONSHIP BETWEEN THE DEGENERATIVE CHANGES IN THE MANDIBULAR CONDYLE AND ARTICULAR EMINENCE INCLINATION, HEIGHT, AND SHAPE: A CBCT STUDY
}

\begin{abstract}
Objectives: This study aimed to analyze any relationship between the articular eminence inclination, height and shape and degenerative condylar changes using cone-beam computed tomography (CBCT).
\end{abstract}

Materials and Methods: The assessments were established on CBCT images of 566 temporomandibular joints (TMJ) that were included from the archive. Age and sex were recorded for all individuals. Degenerative changes were examined on the articular surface of the condyle. The articular eminence (AE) inclination and height measurements were performed on central parasagittal slices of the TMJs. The shape of the AE was classified as box-shaped, sigmoid, flattened, and deformed.

Results: The prevalence of degenerative changes in the condyle was higher in males, but no significant difference was found $(p>0.05)$. Mean AE inclination and height were greater in males than females $(p<0.05)$. Reduced mean eminence inclination and height values were detected in the +50 -year-old group $(p<0.05)$. Sigmoid and box-shaped articular eminence morphologies were more common. The eminence with a deformed shape was related to two or more degenerative alterations in the condylar head.

Conclusion: The eminence inclination and height are associated with the presence and types of degenerative condylar changes. There are significant relationships between sex-AE morphology and age-AE morphology.

Keywords: Articular eminence, Cone-beam computed tomography, Degenerative change, Mandibular condyle, Temporomandibular joint.

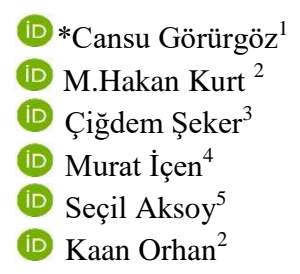

ORCID IDs of the authors:

C.G. $\quad 0000-0002-3083-1660$

M.H.K. 0000-0001-8312-5674

Ç.Ş. $\quad$ 0000-0001-8984-1241

M.İ. $\quad 0000-0002-2779-5646$

S.A. $\quad 0000-0002-6400-4911$

K.O. 0000-0001-6768-0176

\footnotetext{
${ }^{1}$ Bursa Uludağ University, Faculty of Dentistry, Department of Dentomaxillofacial Radiology, Bursa, Turkey.

2 Ankara University, Faculty of Dentistry, Department of Dentomaxillofacial Radiology, Ankara, Turkey.

${ }^{3}$ Zonguldak Bülent Ecevit University, Faculty of Dentistry, Department of Dentomaxillofacial Radiology, Zonguldak, Turkey.

${ }^{4}$ Nevşehir Hacı Bektaş Veli University, Faculty of Dentistry, Department of Dentomaxillofacial Radiology, Nevşehir, Turkey.

5 Near East University, Faculty of Dentistry, Department of Dentomaxillofacial Radiology, Nicosia, Cyprus.
}

$\begin{array}{ll}\text { Received } & : 09.06 .2021 \\ \text { Accepted } & : 21.12 .2021\end{array}$

How to Cite Görürgöz C, Kurt MH, Şeker Ç, İçen M, Aksoy S, Orhan K. Relationship Between the Degenerative Changes in the Mandibular Condyle and Articular Eminence Inclination, Height, and Shape: A CBCT Study. Cumhuriyet Dent J 2021;24:4:403-414.

*Corresponding Author:

Bursa Uludağ University, Faculty of Dentistry, Dentomaxillofacial Radiology Department, 16059 Bursa, Turkey.

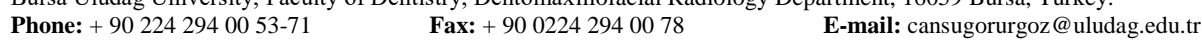




\section{INTRODUCTION}

The temporomandibular joint (TMJ) is known as the most complex articular system in the human organism, and connects the mandible to the temporal bone. ${ }^{1}$ It has the capability of moving in the three planes of space, and the structures of the TMJ are important to sustain a balanced stomatognathic system. The mandibular condylar process constitutes the inferior bone part and the glenoid fossa constitutes the superior bone part of the TMJ. ${ }^{2}$

The articular eminence (AE) is a part of the temporal bone on which the mandibular condyle and the articular disc complex slides in the course of the opening and closing cycles of the mouth. The morphology of the AE enables the path of the condylar movements to flow naturally; it varies within the population and can also change due to age, sex, and masticatory function., ${ }^{2,3}$ The eminence inclination is an essential component in the entire masticatory system and biomechanics of the TMJ.

In TMJ disorders, several changes can be detected in the subarticular surfaces of the condyle and the glenoid fossa. ${ }^{7}$ Increased loading of the TMJ generally results in degenerative bone changes of the articular surface of the condyle and fossa. ${ }^{8}$ Condylar bone changes such as loss of articular cortex, various degrees of flattening, erosion of the articular surfaces, osteophyte formation, and sclerosis may be correlated with the $\mathrm{AE}$ inclination, as close relationships exist between these structures. ${ }^{7}$

Several imaging techniques or different modalities have been used to analyze the eminence inclination, such as computed tomography (CT), ${ }^{7}$ dry skull measurements, ${ }^{8}$ conventional radiography ${ }^{9}$ and tomography, ${ }^{10}$ and magnetic resonance imaging (MRI). ${ }^{11,12}$

The Diagnostic Criteria for Temporomandibular Disorders (DC/TMD) state that scanning is the reference standard for the diagnosis of degenerative joint disease. ${ }^{13}$ Recently, cone-beam computed tomography (CBCT) has been accepted as an alternative to conventional $\mathrm{CT}$ to diagnose hard tissue components of the dentomaxillofacial region.
CBCT allows for a shorter scanning time and lower radiation dose, reduced cost, smaller machine, and easier access than conventional CT. ${ }^{14} \mathrm{CBCT}$ is the imaging modality of choice to visualize the bony elements and pathologies of the TMJ in all three dimensions without superposition and structural distortion. $^{15}$

The current study firstly aimed to specify the association between the eminence inclination and height with $\mathrm{AE}$ shapes, and the degenerative condylar changes. Secondly, factors that may affect these variables, such as sex and age groups, were evaluated.

\section{MATERIAL AND METHODS \\ Study design}

The Institutional Ethical Review Board of X University, Faculty of Dentistry approved this retrospective multicenter study with decision number: 14/3 (Ref: 36290600/124), and the study followed the Declaration of Helsinki on medical protocol and ethics.

The G*POWER 3.1 (Heinrich-Heine University of Dusseldorf, Germany) program was performed to determine the sample size. A power analysis revealed that a minimum of 532 cases would provide $>80 \%$ power to detect significant differences with an effect size of 0.34 at a significance level of $\alpha=0.05$.

CBCT images of patients who were referred to the clinics of three university hospitals for several reasons such as orthodontic therapy, TMD, impacted teeth, and airway evaluation without a history of any systemic diseases during the period from 2013 to 2019 were retrospectively evaluated.

The inclusion criteria were images with completely visible TMJs, all posterior teeth present and degenerative bone changes of the mandibular condyle in at least one TMJ in CBCT images. Low quality images were not evaluated. The radiologic evidence of bone disease (especially osteoporosis), noticeable periodontal diseases, skeletal asymmetries or trauma, developmental or congenital disorders, systemic diseases that may affect joint morphology such as rheumatoid arthritis, prosthetic restorations, a 
history of surgery as well as any tumor or malignancy were exclusion criteria for the study. The final sample was narrowed to 289 cases and 566 TMJs were analyzed in this study.

\section{Imaging procedures}

The same standardized scanning protocols were performed for acquiring CBCT images. Technical parameters and dedicated software of the CBCT machines used are summarized in Table 1.

Table 1: Technical parameters and dedicated software of used CBCTs

\begin{tabular}{|c|c|c|c|c|}
\hline & & ProMax®3D Max & $\begin{array}{l}\text { CBCT Units } \\
\text { NewTom 3G® } \\
\end{array}$ & Veraviewepocs 3D® \\
\hline \multirow{5}{*}{$\begin{array}{l}\text { Technical } \\
\text { parameters }\end{array}$} & FOV sizes & $90 \times 100 \mathrm{~mm}, 230 \times 160 \mathrm{~mm}$ & 12-inch & $40 \times 80 \mathrm{~mm}$ \\
\hline & voxel size & $0.200 \mathrm{~mm}^{3}, 0.400 \mathrm{~mm}^{3}$ & $0.300 \mathrm{~mm}^{3}$ & $0.125 \mathrm{~mm}^{3}$ \\
\hline & $\mathbf{k V p}$ & 96 & 120 & 90 \\
\hline & $\mathbf{m A}$ & $8-12$ & $3-5$ & 5 \\
\hline & scan time $(\mathrm{s})$ & $9-15$ & & 9.4 \\
\hline \multicolumn{2}{|c|}{ Software programs } & Romexis $3.7^{\mathrm{a}}$ & NNT $3.0^{\mathrm{b}}$ & 3D Tomo $\mathrm{X}^{\mathrm{c}}$ \\
\hline Monitor & & $\begin{array}{l}\text { NEC MultiSync }^{\mathrm{d}} \\
\text { 21.3-inch flat-panel } \\
2048 \text { x } 2560 \text { pixel } \\
\text { resolution }\end{array}$ & $\begin{array}{l}\text { Nio Color } 3 \mathrm{MP}^{\mathrm{e}} \\
2048 \text { x } 1536 \text { pixel } \\
\text { resolution }\end{array}$ & $\begin{array}{c}\text { EIZO RadiForce }^{\mathrm{f}} \\
\text { MS230W } \\
23 \text { inch LCD monitor }\end{array}$ \\
\hline
\end{tabular}

$C B C T$ cone beam CT, $F O V$ field of view, $k V p$ Kilovoltage peak, $m A$ milliampere, $s$ second

Promax 3D Max by Planmeca, Helsinki, Finland;

NewTom $3 \mathrm{G}$ by Quantitative Radiology, Verona, Italy;

Veraviewepocs 3D by J Morita MFG Corp., Kyoto, Japan

${ }^{a}$ Romexis 3.7, by Planmeca Oy, Helsinki, Finland; ' $N$ NT 3.0 by Quantitative Radiology, Verona, Italy; ${ }^{\text {c } 3 D ~ T o m o ~ X ~ b y ~ I O R B, ~ B r a s i l i a ~ D F ~ B r a z i l ~}$

${ }^{\mathrm{d}}$ NEC MultiSync by Munchen, Germany; ${ }^{\mathrm{e}}$ Nio Color 3MP by Barco, Kortrijk, Belgium; ${ }^{\mathrm{f}}$ EIZO RadiForce MS230W by Eizo Nanao Corporation, Ishikawa, Japan

\section{CBCT evaluations}

The images were analyzed by one informed and calibrated oral radiologist (CG with six years of experience, MI and SA with over ten years of experience) at each center by using the scanner's software programs. Before the evaluation, a standard positioning was defined and each image was placed in that position by the examiners.

In the axial view, the patient's sagittal median plane was adjusted to the vertical reference line. In the sagittal view, the hard palate was positioned so that the investigator could view the anterior nasal spine and the posterior nasal spine and was then tilted to overlap the horizontal reference line. Thus, the reference line was aligned with the palatine plane (PP).

For secondary reconstruction, the axial view on which the condylar processes were seen with their widest mediolateral extent was used as a reference view. The paracoronal slices $(1 \mathrm{~mm}$ thick) were made along the long axis of the condyle, and the parasagittal slices were obtained perpendicular to the paracoronal plane (Figure 1).

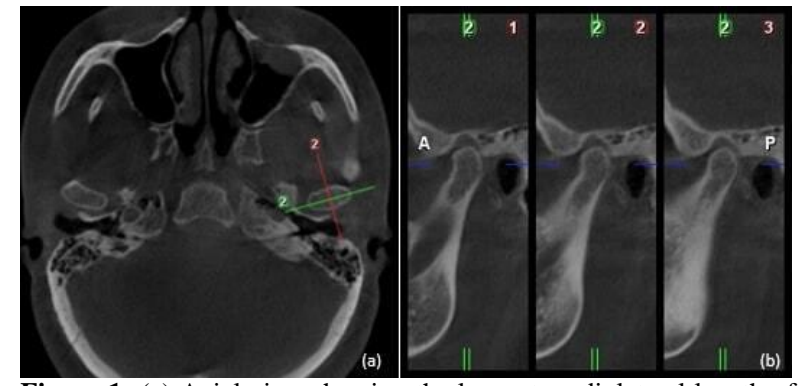

Figure 1: (a) Axial view showing the longest mediolateral length of the condyle. Paracoronal slice of the condyle (green line) and parasagittal slice of the condyle (red line). (b) Parasagittal reconstruction of the temporomandibular joint in maximum intercuspation.

Age, sex, condylar bone changes, articular eminence shapes, and measurements were noted on an evaluation sheet for each case. To prevent misinterpretation, the observed degenerative changes had to be detected in at least two consecutive slices. The image excluded any doubt about which classification choice was decisive. The three examiners were asked to assess the following radiographic characteristics:

\section{Diagnostic Classification for Condylar Bone Change}

The degenerative changes of the condyles were classified according to previously reported definitions as follows: ${ }^{16}$ flattening (Figure 2a); 
sclerosis (Figure 2b); erosion (Figure 2c); osteophytes (Figure 2d); and combination of two or more degenerative condylar changes (Figure 2e).

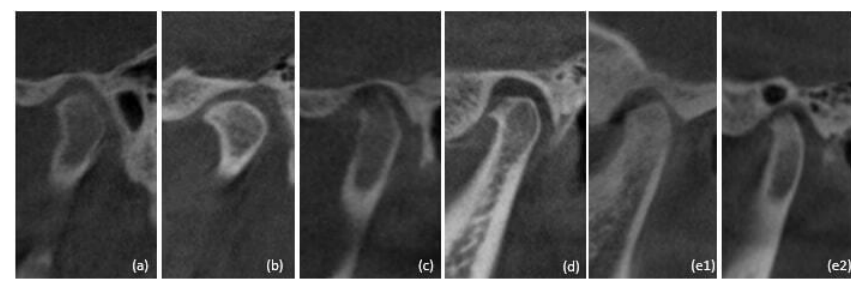

Figure 2: The classification of the degenerative condylar bone changes (a) flattening; (b) sclerosis; (c) erosion; (d) osteophyte; (e) combination of two or more degenerative changes. e1: flattening and sclerosis, e2: flattening, sclerosis, and erosion.

\section{Measurements}

All measurements were performed on the central parasagittal slice of the TMJ. The eminence height was measured by tracing two parallel lines that were parallel to the PP, one tangent to the highest point of the glenoid fossa and another tangent to the lowest point of the articular eminence. Between those two lines, the distance was measured as the eminence height (Figure 3a).

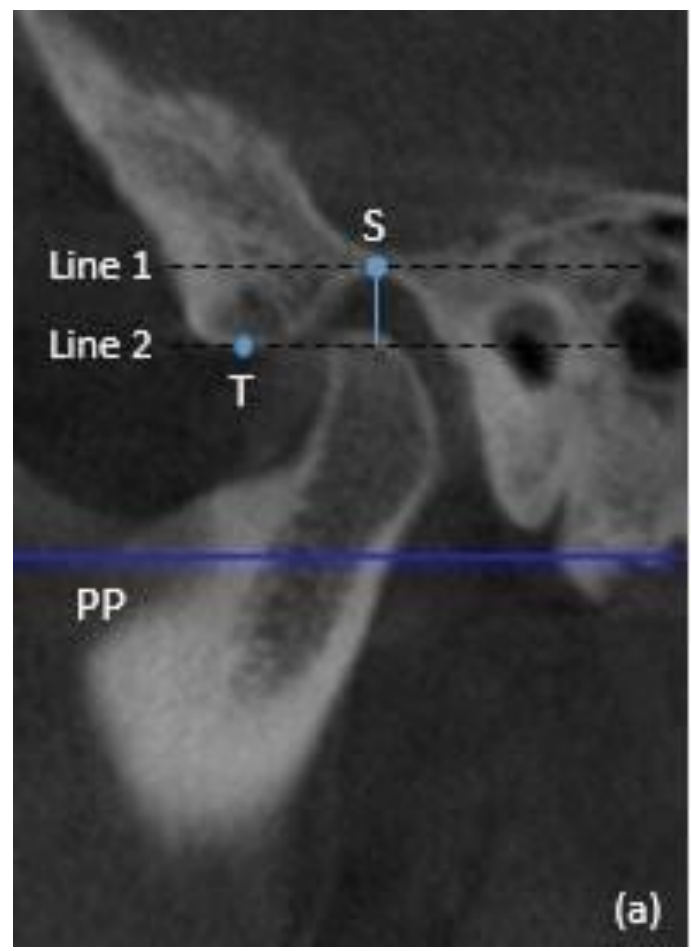

Figure 3a: Articular eminence height.

To detect the eminence inclination, the same parallel lines were used as reference. The internal angle formed between line A (passing through the highest point in the roof of the glenoid fossa and the lowest point at the crest of the articular eminence) and line $\mathrm{B}$ (parallel to the palatine plane) was used to define the value of $\mathrm{AE}$ inclination (Figure 3b).

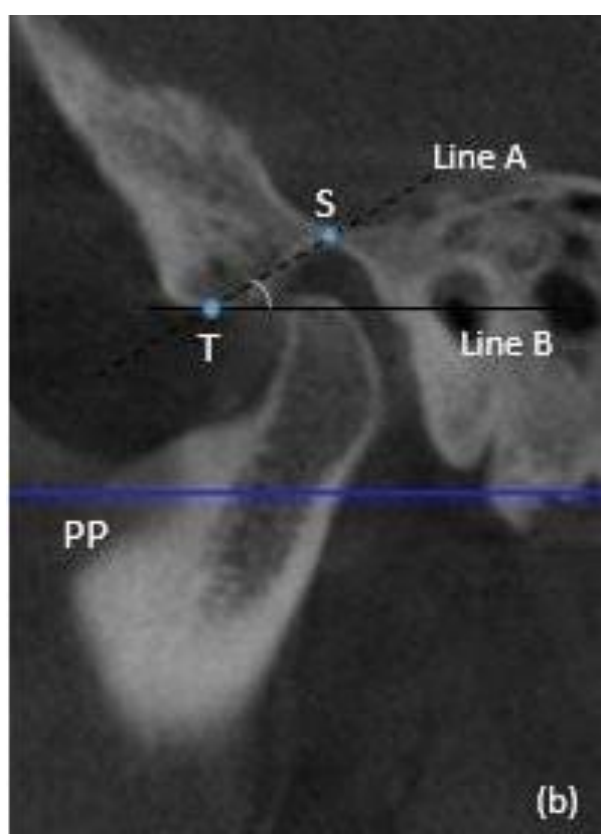

Figure 3b: Articular eminence inclination. Line 1: the parallel line to the PP passing through the highest point of the glenoid fossa, Line 2: the parallel line to the PP passing through the lowest point of the articular eminence. $P P$ palatal plane, $S$ highest point of glenoid fossa, $T$ lowest point of articular eminence.

\section{Articular Eminence Morphology}

The AE morphology was classified into four types, according to the classification of Kurita et al. ${ }^{17}$ (2000): box-shaped, sigmoid, flattened or deformed. In the closed-mouth position, the central parasagittal TMJ slices were evaluated. The box shape represents a deep fossa with a steep posterior articular eminence inclination, while the sigmoid shape represents a continuously S-shaped slope. The flattened eminence has a smooth eminence and therefore a shallow fossa. If the eminence morphology failed to fit one of these three categories, it was classified as deformed (Figure 4).
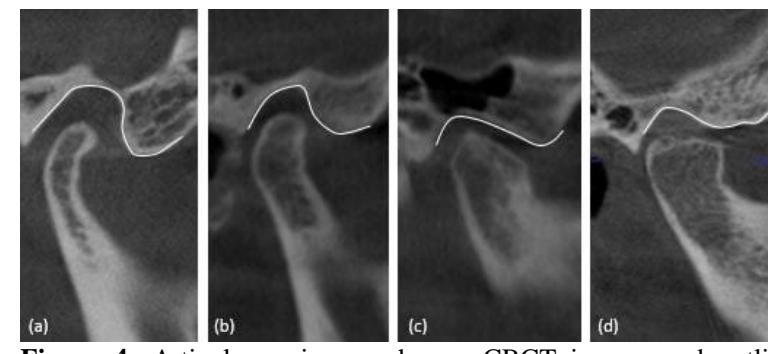

Figure 4: Articular eminence shapes. CBCT images and outline drawings to represent the four shapes of the eminence classified in this study. (a) box-shaped, (b) sigmoid, (c) flattened, (d) deformed.

\section{Statistical Analysis}

Data analysis was performed using the IBM SPSS Statistics 21.0 (Statistical Package for Social Sciences) program. The Student $t$-test and/or Mann-Whitney $U$ test were performed for the comparison of two independent groups. 
Comparison among three or more groups was performed by analysis of variance (ANOVA test) and/or Kruskal-Wallis $\mathrm{H}$ test. The categorical variables were analyzed using the Chi-square test. A probability level of less than $0.05(p<0.05)$ was considered to be significant.

\section{RESULTS}

Degenerative condylar changes were observed in 480 of the 566 joints. Eighty-six TMJs had no changes. The distributions of the presence and types of the degenerative changes in TMJs according to sex and age groups are presented in Figure 5 and Figure 6.

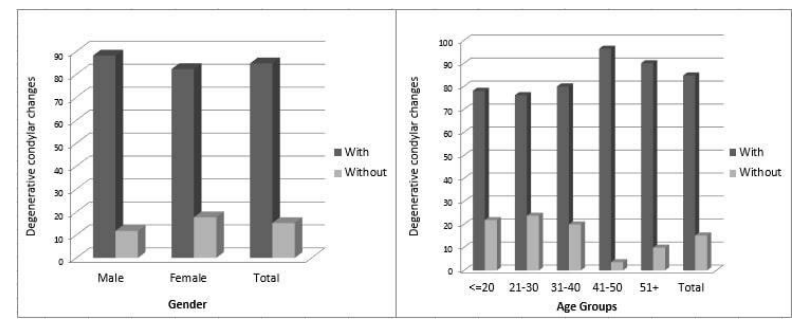

Figure 5: Bar graphs show the distribution of the presence of degenerative condylar changes according to sex and age groups.

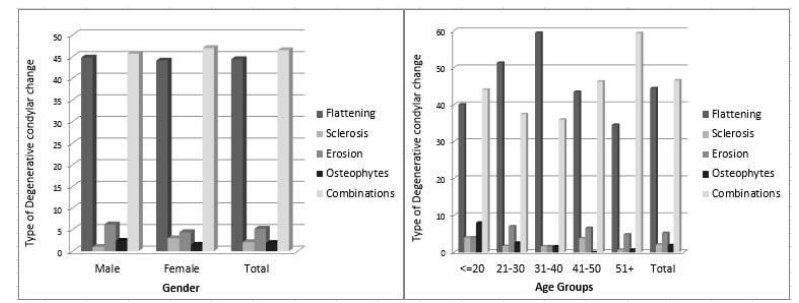

Figure 6: Bar graphs show the distribution of the types of degenerative condylar changes according to sex and age groups.
Regarding the age groups, individuals aged 30 years and older showed higher prevalence of degenerative condylar changes and this difference was statistically significant $(p=0.001)$. For sex, the prevalence of degenerative findings was higher in males $(88.2 \%)$ than in females $(82.3 \%)$ but, this difference was not statistically significant $(p=0.053)$. The prevalence of the degenerative change types was higher for combination $(46.5 \%)$ followed by flattening (44.4\%), erosion (5.2\%), sclerosis $(2.1 \%)$, and osteophytes (1.9\%).

The mean results of eminence inclination and height according to sex and age groups are shown in Table 2. There was a significant difference between the metric variables of the $\mathrm{AE}$ according to sex. The eminence inclination and height in males were higher than those of females $(p=$ 0.0001). Additionally, the mean values of eminence inclination and height in the +50 -yearold group were found to be statistically lowest among age groups $(p=0.0001)$.

\begin{tabular}{|c|c|c|c|c|c|c|}
\hline & & $\mathbf{n}$ & $\begin{array}{c}\text { Eminence inclination mean } \\
\pm \mathbf{s d}\end{array}$ & $p$ value & $\begin{array}{l}\text { Eminence height } \\
\text { mean } \pm \text { sd }\end{array}$ & $p$ value \\
\hline \multirow{3}{*}{ Sex } & Female & 328 & $33.6 \pm 9.3$ & \multirow{3}{*}{$0.0001 *$} & $6.22 \pm 1.96$ & \multirow[t]{3}{*}{$0.0001 *$} \\
\hline & Male & 238 & $37.0 \pm 8.6$ & & $6.87 \pm 1.75$ & \\
\hline & Total & 566 & $35.0 \pm 9.2$ & & $6.49 \pm 1.90$ & \\
\hline & $\leq 20$ & 64 & $35.5 \pm 9.5$ & \multirow[t]{6}{*}{$0.001 * *$} & $7.16 \pm 2.07$ & \multirow[t]{6}{*}{$0.0001 * *$} \\
\hline & $21-30$ & 151 & $35.5 \pm 9.5$ & & $6.79 \pm 1.91$ & \\
\hline Age & $31-40$ & 80 & $36.6 \pm 8.5$ & & $6.67 \pm 1.67$ & \\
\hline \multirow[t]{3}{*}{ Groups } & $41-50$ & 110 & $36.7 \pm 9.1$ & & $6.80 \pm 1.89$ & \\
\hline & $51 \leq$ & 161 & $32.4 \pm 8.6$ & & $5.65 \pm 1.68$ & \\
\hline & Total & 566 & $35.0 \pm 9.2$ & & $6.49 \pm 1.90$ & \\
\hline
\end{tabular}

* Statistically significant differences ( $p<0.05), s d$ standard deviation, $n$ number of TMJs ,by Student's $t$-test

**Statistically significant differences $(\mathrm{p}<0.05)$, sd standard deviation, $\mathrm{n}$ number of TMJs, by one-way ANOVA

The most common AE shape was the boxshape (223 cases; 39.4\%), followed by sigmoid (191 cases; 33.7\%), flattened (111 cases; $19.6 \%$ ), and deformed (41 cases; $7.2 \%$ ). Concerning the variations in the shape of the $\mathrm{AE}$, there was a significant difference between sexes $(p>0.05)$.
Box-shaped eminences were observed most frequently in males; sigmoid-shaped eminences were observed most frequently in females. The prevalence of $\mathrm{AE}$ morphology according to sex and age groups are shown in Table 3. 
Table 3: Distribution of the articular eminence morphology with sex and age groups

\begin{tabular}{|c|c|c|c|c|c|c|c|c|c|}
\hline \multirow{2}{*}{$\begin{array}{l}\text { Articular } \\
\text { Eminence } \\
\text { morphology }\end{array}$} & \multicolumn{3}{|c|}{ Sex } & \multicolumn{6}{|c|}{ Age Groups } \\
\hline & $\begin{array}{l}\text { Male } \\
\mathrm{n}(\%)\end{array}$ & $\begin{array}{c}\text { Female } \\
\mathrm{n}(\%)\end{array}$ & $\begin{array}{l}\text { Total } \\
\mathrm{n}(\%)\end{array}$ & $\begin{array}{c}\leq 20 \\
\mathrm{n}(\%)\end{array}$ & $\begin{array}{l}21-30 \\
\mathrm{n}(\%)\end{array}$ & $\begin{array}{l}31-40 \\
\mathrm{n}(\%)\end{array}$ & $\begin{array}{l}41-50 \\
\mathrm{n}(\%)\end{array}$ & $\begin{array}{c}51 \leq \\
\mathrm{n}(\%)\end{array}$ & $\begin{array}{l}\text { Total } \\
\mathrm{n}(\%)\end{array}$ \\
\hline Box & $\begin{array}{c}83 \\
(34.9)\end{array}$ & $\begin{array}{c}140 \\
(42.7)\end{array}$ & $\begin{array}{c}223 \\
(39.4)\end{array}$ & $\begin{array}{c}27 \\
(42.2)\end{array}$ & $\begin{array}{c}68 \\
(45.0)\end{array}$ & $\begin{array}{c}24 \\
(30.0)\end{array}$ & $\begin{array}{c}40 \\
(36.4)\end{array}$ & $\begin{array}{c}64 \\
(39.8)\end{array}$ & $\begin{array}{c}223 \\
(39.4)\end{array}$ \\
\hline Sigmoid & $\begin{array}{c}101 \\
(42.4)\end{array}$ & $\begin{array}{c}90 \\
(27.4)\end{array}$ & $\begin{array}{c}191 \\
(33.7)\end{array}$ & $\begin{array}{c}19 \\
(29.7)\end{array}$ & $\begin{array}{c}45 \\
(29.8)\end{array}$ & $\begin{array}{c}37 \\
(46.3)\end{array}$ & $\begin{array}{c}44 \\
(40.0)\end{array}$ & $\begin{array}{c}46 \\
(28.6)\end{array}$ & $\begin{array}{c}191 \\
(33.7)\end{array}$ \\
\hline Flattened & $\begin{array}{c}32 \\
(13.4)\end{array}$ & $\begin{array}{c}79 \\
(24.1)\end{array}$ & $\begin{array}{c}111 \\
(19.6)\end{array}$ & $\begin{array}{c}13 \\
(20.3)\end{array}$ & $\begin{array}{c}29 \\
(19.2)\end{array}$ & $\begin{array}{c}16 \\
(20.0)\end{array}$ & $\begin{array}{c}20 \\
(18.2)\end{array}$ & $\begin{array}{c}33 \\
(20.5)\end{array}$ & $\begin{array}{c}111 \\
(19.6)\end{array}$ \\
\hline Deformed & $\begin{array}{c}22 \\
(9.2)\end{array}$ & $\begin{array}{c}19 \\
(5.8)\end{array}$ & $\begin{array}{c}41 \\
(7.2)\end{array}$ & $\begin{array}{c}5 \\
(7.8)\end{array}$ & $\begin{array}{c}9 \\
(6.0)\end{array}$ & $\begin{array}{c}3 \\
(3.8)\end{array}$ & $\begin{array}{c}6 \\
(5.5)\end{array}$ & $\begin{array}{c}18 \\
(11.2)\end{array}$ & $\begin{array}{c}41 \\
(7.2)\end{array}$ \\
\hline Total & $\begin{array}{c}238 \\
(100.0)\end{array}$ & $\begin{array}{c}328 \\
(100.0)\end{array}$ & $\begin{array}{c}566 \\
(100.0)\end{array}$ & $\begin{array}{c}64 \\
(100.0)\end{array}$ & $\begin{array}{c}151 \\
(100.0)\end{array}$ & $\begin{array}{c}80 \\
(100.0)\end{array}$ & $\begin{array}{c}110 \\
(100.0)\end{array}$ & $\begin{array}{c}161 \\
(100.0)\end{array}$ & $\begin{array}{c}566 \\
(100.0)\end{array}$ \\
\hline$p$ value & & $0.0001^{*}$ & & & & & 168 & & \\
\hline
\end{tabular}

* Statistically significant differences $(\mathrm{p}<0.05)$, n number of TMJs, by the Chi-square test

No association was found between the AE shape and age groups. ( $p>0.05)$. Additionally, the metric variables of the $\mathrm{AE}$ were significantly higher in sigmoid and box-shaped groups compared to other groups $(p=0.0001)$ (Table 4$)$.

Table 4: The mean eminence inclination and eminence height values according to articular eminence morphology

\begin{tabular}{llccccc}
\hline & & $\mathbf{n}$ & $\begin{array}{c}\text { Eminence inclination } \\
\text { mean } \pm \text { sd }\end{array}$ & $\boldsymbol{p}$ value & $\begin{array}{c}\text { Eminence height } \\
\text { mean } \pm \text { sd }\end{array}$ & $\boldsymbol{p}$ value \\
\hline & Box & 191 & $\mathbf{4 1 . 3} \pm \mathbf{7 . 0}$ & $0.0001^{*}$ & $\mathbf{7 . 6 7} \pm \mathbf{1 . 5 7}$ & $0.0001 *$ \\
Articular & Sigmoid & 223 & $\mathbf{3 4 . 2} \pm \mathbf{7 . 3}$ & & $\mathbf{6 . 1 7} \pm \mathbf{1 . 6 5}$ \\
Eminence & Flattened & 111 & $27.4 \pm 8.4$ & $5.33 \pm 1.87$ \\
morphology & Deformed & 41 & $30.8 \pm 9.2$ & $5.93 \pm 1.83$ \\
& Total & 566 & $35.0 \pm 9.2$ & $6.49 \pm 1.90$ \\
\hline
\end{tabular}

* Statistically significant differences ( $\mathrm{p}<0.0001$ ), sd standard deviation, $\mathrm{n}$ number of TMJs, by one-way ANOVA

The mean values of eminence inclination and presented according to presence and types of the height were analyzed, and the results are degenerative changes (Table 5).

Table 5: The eminence inclination and eminence height values according to presence and types of degenerative condylar changes

\begin{tabular}{|c|c|c|c|c|c|c|}
\hline & & $\mathbf{n}$ & $\begin{array}{c}\text { Eminence inclination } \\
\text { mean } \pm \text { sd }\end{array}$ & $p$ value & $\begin{array}{c}\text { Eminence height } \\
\text { mean } \pm \text { sd }\end{array}$ & $p$ value \\
\hline \multirow{4}{*}{$\begin{array}{l}\text { Degenerative } \\
\text { Condylar } \\
\text { Changes }\end{array}$} & Without & 86 & $36.9 \pm 8.7$ & & $6.90 \pm 1.71$ & $0.049 *$ \\
\hline & With & 480 & $34.7 \pm 9.2$ & 0.073 & $6.42 \pm 1.93$ & \\
\hline & Total & 566 & $35.0 \pm 9.2$ & & $6.49 \pm 1.90$ & \\
\hline & Flattening & 213 & $36.0 \pm 9.2$ & $0.015 * *$ & $6.60 \pm 1.90$ & 0.089 \\
\hline \multirow{5}{*}{$\begin{array}{l}\text { Types of } \\
\text { Degenerative } \\
\text { Condylar } \\
\text { Changes }\end{array}$} & Sclerosis & 10 & $38.6 \pm 9.0$ & & $7.07 \pm 2.0$ & \\
\hline & Erosion & 25 & $35.0 \pm 11.6$ & & $6.41 \pm 2.21$ & \\
\hline & Osteophytes & 9 & $35.0 \pm 4.7$ & & $7.10 \pm 1.82$ & \\
\hline & Combinations & 223 & $33.2 \pm 8.9$ & & $6.20 \pm 1.91$ & \\
\hline & Total & 480 & $34.7 \pm 9.2$ & & $6.42 \pm 1.93$ & \\
\hline
\end{tabular}

No significant differences were observed between the eminence inclination and condyles either with bone change or without $(p>0.05)$. Considering the eminence height values, there was a significant difference according to the presence or absence of degenerative alterations $(p=0.049)$, which showed higher values in condyles without change group (Table 5). The mean values of eminence 
inclination were significantly higher in the sclerosis-type degenerative change group compared to other groups and were significantly lower in the combination-type group compared to the flattening, erosion and osteophyte groups $(p<0.05)$. There was no statistical relationship between the eminence height and types of degenerative condylar change.
In terms of the $\mathrm{AE}$ morphology, sigmoid and box shapes were the most common forms, although no statistically significant difference was found between both groups $(p>0.05)$ (Table 6). Additionally, the combination of two or more degenerative alterations in the condyle was associated with the deformed form, but flattening was observed most frequently in the box-shaped and sigmoid forms (Table 7).

Table 6: Distribution of the articular eminence shapes on with and without degenerative changes groups.

\begin{tabular}{|c|c|c|c|c|c|c|c|c|}
\hline \multirow{3}{*}{$\begin{array}{c}\text { Articular Eminence } \\
\text { morphology }\end{array}$} & \multicolumn{6}{|c|}{ Presence of Degenerative condylar changes } & \multirow[b]{3}{*}{$\chi^{2}$} & \multirow[b]{3}{*}{$p$ value } \\
\hline & \multicolumn{2}{|c|}{ Without } & \multicolumn{2}{|c|}{ With } & \multicolumn{2}{|c|}{ Total } & & \\
\hline & n & $\%$ & n & $\%$ & $\mathbf{n}$ & $\%$ & & \\
\hline Box & 30 & 15.7 & 161 & 84.3 & 191 & 100.0 & & \\
\hline Sigmoid & 47 & 21.1 & 176 & 78.9 & 223 & 100.0 & & \\
\hline Flattened & 9 & 8.1 & 102 & 91.9 & 111 & 100.0 & 17,6 & $0.0001 *$ \\
\hline Deformed & 0 & 0.0 & 41 & 100.0 & 41 & 100.0 & & \\
\hline Total & 86 & 15.2 & 480 & 84.8 & 566 & 100.0 & & \\
\hline
\end{tabular}

* Statistically significant differences $(\mathrm{p}<0.0001)$, $\mathrm{n}$ number of TMJs, by the Chi square test

Table 7: Distribution of the AE morphology according to types of degenerative change present in the condyles

\begin{tabular}{|c|c|c|c|c|c|c|c|}
\hline \multirow{2}{*}{$\begin{array}{l}\text { Articular } \\
\text { Eminence } \\
\text { morphology }\end{array}$} & \multirow[b]{2}{*}{$\begin{array}{c}\text { Flattening } \\
\mathbf{n}(\%)\end{array}$} & \multicolumn{5}{|c|}{ Types of Degenerative Bone Changes } & \multirow[b]{2}{*}{$p$ value } \\
\hline & & $\begin{array}{c}\text { Sclerosis } \\
\text { n (\%) }\end{array}$ & $\begin{array}{c}\text { Erosion } \\
\text { n }(\%)\end{array}$ & $\begin{array}{c}\text { Osteophytes } \\
\text { n (\%) }\end{array}$ & $\begin{array}{c}\text { Combinations } \\
\text { n }(\%)\end{array}$ & $\begin{array}{l}\text { Total } \\
\text { n }(\%)\end{array}$ & \\
\hline Box & $78(36.6)$ & $7(70.0)$ & $9(36.0)$ & $2(22.2)$ & $65(29.1)$ & $161(33.5)$ & $0.0001^{*}$ \\
\hline Sigmoid & 86 (40.4) & $2(20.0)$ & $12(48.0)$ & $4(44.4)$ & $72(32.3)$ & $176(36.7)$ & \\
\hline Flattened & $44(20.7)$ & $0(0.0)$ & $4(16.0)$ & $1(11.1)$ & $53(23.8)$ & $102(21.3)$ & \\
\hline Deformed & $5(2.3)$ & $1(10.0)$ & $0(0.0)$ & $2(22.2)$ & $33(14.8)$ & $41(8.5)$ & \\
\hline Total & $213(100.0)$ & $10(100.0)$ & $25(100.0)$ & $9(100.0)$ & $223(100.0)$ & $480(100.0)$ & \\
\hline
\end{tabular}

* Statistically significant differences ( $p<0.0001), n$ number of TMJs, by the Chi square test with Monte Carlo simulation

\section{DISCUSSION}

In the literature, the two main ways to measure the AE inclination are defined as follows: the best-fit line method, which involves adjusting a line drawn to the posterior slope of the eminence, and the top-roof line method, which involves connecting the highest point of the glenoid fossa and the lowest point of the eminence. The angle is established by measurement between the selected line and a horizontal reference plane. Both techniques have been used in various studies and result in similar values for $\mathrm{AE}$ angulation. ${ }^{18-20}$ It has been suggested that the top-roof line method considers the position of the eminence crest relative to the glenoid fossa roof, whereas the other method considers the posterior surface of the AE. Thus, the actual condylar path can be determined by the best-fit line method, while the top-roof line figures out the morphology of the eminence better. The current study aimed to analyze the TMJ morphology, so the top-roof line technique was preferred. ${ }^{21}$

The inclination of the $\mathrm{AE}$ is described as the angle between the posterior wall of the eminence and a horizontal reference plane such as the Frankfort horizontal plane, occlusal plane or palatal plane. ${ }^{22}$ The Frankfort horizontal plane has been commonly preferred in the previous studies. ${ }^{12,18,21}$ In this study, the evaluations were made to refer to the palatal plane, since some of the FOV sizes of images did not cover the anterior part of the orbital floor. Also, the PP is a useful indicator for image orientation in the axial and sagittal slices. ${ }^{22}$ 
It is important to use standardized protocols that can make accurate and reliable measurements in the best representation of the evaluated structure. Sülün et al. ${ }^{12}$ (2001) and Ren et al. ${ }^{23}$ (1995) performed the measurements of the AE on central, lateral, and medial slices. The central sagittal section of the condylar process is the steepest part of the $\mathrm{AE}$, and therefore the most appropriate slice for analyzing. Several studies used this section for obtaining accurate results. ${ }^{18,21,22}$ In our analysis, measurements were made on a single parasagittal section.

The TMJ allows a large range of mandibular movements and exposes the functional loads from different types of activities, and provides the transmission of forces and loads to the cranial base. ${ }^{24}$ The AE is an important structure in the biomechanics of the TMJ and consists of thick and dense bone, which is suitable for mechanical forces and loads. ${ }^{1}$ The relationship between the AE inclination and several factors such as TMD or internal derangement ${ }^{12,17,25}$, sex ${ }^{19,20}$, age ${ }^{19,22}$, malocclusion ${ }^{6}$, and changes in dentition ${ }^{24}$ has been evaluated in previous studies. However, there is limited data related to degenerative condylar changes and the eminence inclination.

In a study with dry human skulls, Pirttiniemi et $a l .{ }^{27}$ (1990) confirmed a functional dependence relationship between the mandibular condyle and articular eminence. In an animal experiment with mouse models, it was suggested that glenoid fossa growth was initiated, but that the continuous development of this structure could not be sustained in the case of absence or dislocation of the condyle. ${ }^{28}$

In the literature, the $\mathrm{AE}$ inclination and height have been assessed according to the presence of osteoarthritic changes. Some investigators reported that $\mathrm{AE}$ inclination in condyles with osteoarthritic changes was significantly lower than without changes. Sa et $a l .{ }^{22}$ (2017) mentioned that condylar changes did not affect the value of eminence inclination, but an average reduction in eminence inclination was detected when combination-type degeneration was present. Similarly, we could not find any significant difference between the AE inclination and presence of condylar change. However, steeper inclination was observed in the sclerosistype condylar change group than in other groups. In the combination-type (two or more condylar changes) group, more shallow inclination was detected, a result that may be due to the more serious effects of two or more bone changes.

In this study, the mean eminence height value was lower in individuals with degenerative condylar change $(p<0.05)$. The eminence height in cases with osteophytes had higher values, while in the combination-type group, a reduced eminence height value was detected. However, no significant difference was found when all types were evaluated together $(p=0.089)$.

Previous studies evaluated the influencing factors for stress distribution in the condylar region and concluded that morphological alterations in the head of the condyle may change the mechanical loading in the roof of the fossa. ${ }^{19}$ The same relation could be established between the $\mathrm{AE}$ and mandibular condyle. In addition to this, Lee et al. ${ }^{29}$ (2019) hypothesized that osteoarthritic changes can develop in the articular eminence after condylar changes when osteoarthritic alterations are more advanced. The greater values in individuals with sclerotic and osteophytic changes in the articular surface of the condyle may be related to mechanical stimulation. Sclerosis and osteophytes are advanced stages of degenerative changes, reflecting the body's adaptation to repair the TMJ. These degenerative alterations can increase the bone thickness in the articular eminence, as well as change in the stress distribution. Following this, when the combination of two or more changes occurs in the mandibular condyle, adaptation capacity may be insufficient and morphologic alteration in the $\mathrm{AE}$ can be detected.

The comparison between the eminence shapes revealed no significant differences in the presence of degenerative changes $(p>0.05)$. Nevertheless, eminence forms were mainly related to the types of alterations in the condyle. In agreement with this study, Kurita et al. ${ }^{17}$ (2000) stated that greater eminence height and inclination 
values were related to box-shaped eminences and lower values were related to flattened eminences.

It should be noted that the architectural features of the $\mathrm{AE}$ and mandibular condyle are different. The eminence has thick cortices with transversely oriented trabeculae, while the mandibular condyle has vertically oriented fine bony trabeculae. Therefore, these two structures of the TMJ may be affected by the same movements and muscle activities differently. ${ }^{30}$

In the literature, some of the studies associated the articular eminence morphology and internal derangements of the TMJ. Several authors have reported the eminence as a predisposing factor for internal derangement. ${ }^{12,25}$ In contrast, Ren et $a .^{23}$ (1995) concluded that a steeper eminence was detected in symptom-free individuals than in patients with internal derangement. It is also suggested that condylar bone change is more related to the eminence inclination than to the disc displacement condition. The more advanced the disc displacement present, the more frequent bone changes become. Kurita et al. ${ }^{17}$ (2000) observed flattened eminence in TMJs with disc displacement. Nevertheless, whether a greater eminence could be an effect of internal disorders or whether flattened eminence could be a result is still controversial.

It has been reported that morphologic changes can occur in the AE with advanced age, which results from flattening of the eminence in the long term. ${ }^{12,17}$ When analyzing the eminence inclination and height in different age groups, we verified that both mean eminence inclination and height significantly decreased in cases aged over 50 years. In contrast, some authors found no correlation between advanced age and eminence morphometry. ${ }^{8,19,20}$

In the present study, the frequency of degenerative alterations was higher in males than in females, but no significant difference was detected. We suggested that the finding could be due to sex differences in willingness to seek help. The rate of seeking treatment may be lower in men than women, and men may only refer to the hospital at an advanced stage of the disease. These results can be attributed to the fact that the study was designed with randomized subjects at a time interval. Furthermore, the analysis of sex differences in degenerative change frequency resulted in a borderline $p$-value $(p=0.053$, small effect size $=0.0814)$. However, this difference was limited due to the low number of subjects in the study groups.

The relationship between sex and morphometric measurements of the $\mathrm{AE}$ has been evaluated in earlier research studies. Some of these stated a relationship between the eminence inclination and $\mathrm{sex}^{20,23}$, while others did not. ${ }^{4,19}$ Authors who suggested that the inclination changed with sex revealed that males presented higher inclination values. Many studies affirmed a higher eminence height in males compared with females. ${ }^{4,20,21}$ These results agree with those of our study. For the AE morphometry, sex had a statistically significant influence, the mean results being higher for males $(p<0.05)$. The shapes of condylar pathways were also significantly different between females and males. The box shape was significantly more common in males, while in females the most prevalent eminence shape was detected as sigmoid-type. The box shape represents a larger articular eminence or a deeper articular fossa than sigmoid shapes, and the box-shaped eminence presents high $\mathrm{AE}$ inclination and height values. The greater results and morphology in males may be relevant to the relatively larger cranio-caudal sizes in males.

The discrepancy between results may be caused by racial/ethnic diversity of populations or methodological differences in the studies, such as the diagnostic criteria and techniques used, sample size, measurement methods, and age range. Furthermore, decreased adaptive capacity of the articular elements or excessive or sustained loading in the TMJ are predisposing factors in the development of disorders. ${ }^{31,32}$ Even if the biomechanical behaviors are within physiological ranges, ageing, systemic disorders and hormonal changes can affect the remodeling of the TMJ. Mechanical factors, including parafunction, trauma, unstable occlusion, and functional 
overloading affect TMJ internal derangement and osteoarthrosis. These factors can exist alone or be interrelated, interdependent, and/or coexistent. ${ }^{31-33}$

The present study is not free of limitations. Firstly, the soft tissue component of the TMJ, which can play a role in the articular eminence morphology, was not evaluated. Secondly, due to the observational design of the study, the longterm relationship between articular eminence morphology and degenerative changes of the condylar articular surface was not analyzed directly. In addition, this observational design limits the degree of cause-and-effect relationships. Further longitudinal and stratified research with larger sample sizes is necessary to resolve this issue.

\section{CONCLUSIONS}

The presence of two or more degenerative changes in the mandibular condyle resulted in reduced eminence inclination and height and it was more prominent in the deformed eminence shape. The AE inclination and height were influenced by age and sex. It is believed that further studies on this subject will provide a better understanding of the relationships and more definitive conclusions.

\section{ACKNOWLEDGEMENTS}

The authors would like to thank Ahmet Gül for timely statistical support and Philip Smith for manuscript editing.

\section{INFORMED CONSENT}

For this type of study, formal consent is not required.

\section{CONFLICT OF INTEREST}

The authors declare that they have no conflict of interest.

\section{FINANCIAL DISCLOSURE}

The authors declared that this study received no financial support.

\section{Mandibular Kondildeki Dejeneratif Değişiklikler ile Artiküler Eminensin Ĕ̆imi, Yüksekliği ve Şekli Arasındaki İlişki: Bir KIBT Çalışması \\ $\ddot{O} Z$}

Amaç: Bu çalışma, konik ışınlı bilgisayarlı tomografi (KIBT) kullanılarak artiküler eminens (AE) eğim ve yüksekliğini analiz etmeyi, elde edilen sonuçlar eminens şekilleri ve dejeneratif kondiler değişiklikler ile ilişskilendirmeyi amaçlamaktadır. Gereç ve Yöntemler: Toplam 566 temporomandibular eklemin (TME) KIBT görüntüleri değerlendirildi. Tüm bireylerin yaşlar ve cinsiyetleri kaydedildi. Kondil yüzeyindeki dejeneratif değişiklikler incelendi. Artiküler eminens eğim ve yükseklik ölçümleri TME'nin santral parasagital kesitleri üzerinde yapıldı. AE'nin şekli kutu, sigmoid, düz ve deforme olarak sinıflandirıldi. Bulgular: Kondildeki dejeneratif değişikliklerin prevalansı erkeklerde daha fazlayd, ancak cinsiyet ile kondilin dejeneratif değişiklikleri arasında anlamlı bir fark bulunamadı ( $p>0,05)$. AE eğim ve yükseklik ortalamaları erkeklerde daha fazlaydı $(p<0,05)$. Elli yıl üzeri yaş grubunda diğer yaş gruplarına göre eminens ĕgim ve yüksekliğinin ortalama dĕgerlerinin azalmış olduğu tespit edildi $(p<0,05)$. Sigmoid ve kutu şekilli artiküler eminens morfolojileri diğerlerine göre daha yaygındl. Deforme eminens şekilli grupta kombinasyon tip kondiler dejeneratif değişiklikler daha fazla bulundu. Sonuç: Kondildeki dejeneratif değişikliklerin varlı̆̆ ve tipleri ile eminensin ortalama eğim ve yükseklik sonuçlar arasında anlaml farklılıklar tespit edilmiştir. AE morfolojisi cinsiyet ve yaşa göre istatistiksel olarak anlamlı seviyede değişmektedir. Anahtar Kelimeler: Artiküler eminens, konik ışınlı bilgisayarlı tomografi, dejeneratif değişiklik, mandibular kondil, temporomandibular eklem.

\section{REFERENCES}

1. Okeson JP. Management of temporomandibular disorders and occlusion. 7th ed. St Louis: Elsevier Health Sciences, 2014.

2. Pandis N, Karpac J, Trevino R, Williams B. A radiographic study of condyle position at various depths of cut in dry skulls with axially corrected lateral tomograms. Am J Orthod Dentofacial Orthop 1991; 100: 116-122.

3. Estomaguio GA, Yamada K, Saito I. Unilateral condylar bone change, inclination of the posterior slope of the articular eminence and craniofacial morphology. Orthod Waves 2008; 67: 113-119.

4. Wu CK, Hsu JT, Shen YW, Chen JH, Shen WC, Fuh LJ. Assessments of inclinations of the mandibular fossa by computed tomography in an Asian population. Clin Oral Investig 2012; 16: 443-450. 
5. Csadó K, Márton K, Kivovics P. Anatomical changes in the structure of the temporomandibular joint caused by complete edentulousness. Gerodontology 2012; 29: 111-116.

6. Kranjčić J, Vojvodić D, Žabarović D, Vodanović M, Komar D, Mehulić K. Differences in articulareminence inclination between medieval and contemporary human populations. Arch Oral Biol 2012; 57: 1147-1152.

7. Yamada K, Tsuruta A, Hanada K, Hayashi T. Morphology of the articular eminence in temporomandibular joints and condylar bone change. J Oral Rehabil 2004; 31: 438-444.

8. Jasinevicius TR, Pyle MA, Lalumandier JA, Nelson S, Kohrs KJ, Türp JC, et al. Asymmetry of the articular eminence in dentate and partially edentulous populations. Cranio 2006; 24: 85-94.

9. Baccetti T, Antonini A, Franchi L, Tonti M, Tollaro I. Glenoid fossa position in different facial types: a cephalometric study. Br J Orthod 1997;24:55-59.

10. Katsavrias EG. The effect of mandibular protrusive (activator) appliances on articular eminence morphology. Angle Orthod 2003; 73: 647-653.

11. Kurita H, Ohtsuka A, Kobayashi H, Kurashina K. Flattening of the articular eminence correlates with progressive internal derangement of the temporomandibular joint. Dentomaxillofac Radiol 2000;29:277-279.

12. Sülün T, Cemgil T, Duc JM, Rammelsberg $P$, Jäger L, Gernet W. Morphology of the mandibular fossa and inclination of the articular eminence in patients with internal derangement and in symptom-free volunteers. Oral Surg Oral Med Oral Pathol Oral Radiol Endod 2001; 92: 98-107.

13. Schiman E, Ohrbach R, Truelove E, Look J, Anderson G, Goulet -P, et al. Diagnostic Criteria for Temporomandibular Disorders (DC/TMD) for Clinical and Research Applications: Recommendations of the International RDC/TMD Consortium Network* and Orofacial Pain Special Interest Groupy. J. Oral Facial Pain Headache 2014;28:6-27.

14. Hintze H, Wiese M, Wenzel A. Cone beam CT and conventional tomography for the detection of morphological temporomandibular joint changes. Dentomaxillofac Radiol 2007;36:192-197.

15. Kiliç SC, Kiliç N, Sümbüllü MA. Temporomandibular joint osteoarthritis: cone beam computed tomography findings, clinical features, and correlations. Int J Oral Maxillofac Surg 2015;44:12681274.

16. Borahan MO, Mayil M, Pekiner FN. Using cone beam computed tomography to examine the prevalence of condylar bony changes in a Turkish subpopulation. Niger J Clin Pract 2016; 19: 259-266.

17. Kurita H, Ohtsuka A, Kobayashi H, Kurashina K. Is the morphology of the articular eminence of the temporomandibular joint a predisposing factor for disc diplacement? Dentomaxillofac Radiol 2000; 29: 159-162.

18. Çağlayan F, Sümbüllü MA, Akgül HM. Associations between the articular eminence inclination and condylar bone changes, condylar movements, and condyle and fossa shapes. Oral Radiol 2014; 30: 84-91.

19. İlgüy D, İlgüy $M$, Fişekçioğlu E, Dölekoğlu S, Ersan N. Articular eminence inclination, height, and condyle morphology on cone beam computed tomography. Scientific World J 2014;761714.

20. Sümbüllü MA, Cağlayan F, Akgül HM, Yilmaz AB. Radiological examination of the articular eminence morphology using cone beam CT. Dentomaxillofac Radiol 2012;41:234-240.

21. Paknahad M, Shahidi S, Akhlaghian M, Abolvardi M. Is mandibular fossa morphology and articular eminence inclination associated with temporomandibular dysfunction? J Dent (Shiraz) 2016; 17: 134.

22. Sa SC, Melo SLS, Melo DPD, Freitas DQ, Campos PSF. Relationship between articular eminence inclination and alterations of the mandibular condyle: a CBCT study. Braz Oral Res 2017; 31: 25.

23. Ren YF, Isberg A, Westesson PL. Steepness of the articular eminence in the temporomandibular joint: tomographic comparison between asymptomatic volunteers with normal disk position and patients with disk displacement. Oral Surg Oral Med Oral Pathol Oral Radiol Endod 1995;80:258-266.

24.Žabarović D, Jerolimov V, Carek V, Vojvodić D, Žabarović K, Buković D. The effect of tooth loss on the TM-joint articular eminence inclination. Coll Antropol 2000;24:37-42.

25. Gökalp H, Türkkahraman H, Bzeizi N. Correlation between eminence steepness and condyle disc movements in temporomandibular joints with internal derangements on magnetic resonance imaging. Eur $\mathrm{J}$ Orthod 2001; 23: 579-584.

26. Katsavrias EG. Morphology of the temporomandibular joint in subjects with Class II 
Division 2 malocclusions. Am J Orthod Dentofacial Orthop 2006;129:470-478.

27. Pirttiniemi P, Kantomaa T, Ronning O. Relation of glenoid fossa to craniofacial morphology, studied on dry human skulls. Acta Odontol Scand 1990;48:359.

28. Wang Y, Liu C, Rohr J, Liu H, He F, Yu J, et al. Tissue interaction is required for glenoid fossa development during temporomandibular joint formation. Dev Dyn 2011;240:2466.

29. Lee PP, Stanton AR, Schumacher AE, Truelove E, Hollender LG. Osteoarthritis of the temporomandibular joint and increase of the horizontal condylar angle: a longitudinal study. Oral Surg Oral Med Oral Pathol Oral Radiol 2019;127:339-350.

30.Herring SW, Liu ZJ. Loading of the temporomandibular joint: anatomical and in vivo evidence from the bones. Cells Tissues Organs 2001;169:193-200.
31. Arnett GW, Milam SB, Gottesman L. Progressive mandibular retrusion-idiopathic condylar resorption. Part I. Am J Orthod Dentofacial Orthop 1996; 110:8-15. 32. Arnett GW, Milam SB, Gottesman L. Progressive mandibular retrusion-idiopathic condylar resorption. Part II. Am J Orthod Dentofacial Orthop 1996;110: 117-127.

33. Nitzan DW. The process of lubrication impairment and its involvement in temporomandibular joint disc displacement: a theoretical concept. J Oral Maxillofac Surg 2001; 59: 36-45. 